\title{
KNOWLEDGE AND POWER NECESSARY TO RECONSTRUCT NURSING AFTER MANAGEMENT CHANGES AT A TEACHING HOSPITAL
}

\author{
Elizabeth Bernardino \\ Vanda Elisa Andres Felli ${ }^{2}$
}

Bernardino E, Felli VEA. Knowledge and power necessary to reconstruct nursing after management changes at a teaching hospital. Rev Latino-am Enfermagem 2008 novembro-dezembro; 16(6):1032-7.

This study was carried out at a teaching hospital in Southern Brazil, which adopted a management model that provoked the dismantling of the nursing service and the disbandment of nursing professionals. Its general goal was to promote changes that would be implemented in the re-organization of nursing work. It is a case study with a historical-dialectic approach, whose data were collected in March and April 2005 through the focal group technique. The study subjects were eight nurses, two technicians and two nursing auxiliaries. Data were analyzed through thematic content analysis. Results evidenced that the greatest challenges nursing faced at this hospital were: to construct a new identity, carry out teamwork while maintaining its professional identity, acquire visibility in the institution, change care and expand management.

DESCRIPTORS: nursing; organizational innovation; organization and administration

\section{CONOCIMIENTOS Y PODERES NECESARIOS PARA RECONSTRUIR LA ENFERMERÍA FRENTE A LOS CAMBIOS ADMINISTRATIVOS EN UN HOSPITAL DE ENSEÑANZA}

Este estudio fue realizado en un hospital de enseñanza del Sur del país, el cual adoptó un modelo de administración que provocó el desmantelamiento del Servicio de Enfermería y la desmovilización de sus trabajadores. El objetivo general fue promover la construcción de los cambios que deberían ser implementados en la reorganización del trabajo en enfermería. Se trata de estudio de caso con abordaje histórico dialéctico, cuyos datos fueron recolectados entre marzo y abril de 2005, utilizando la técnica de grupo focal. Los sujetos de la investigación fueron 8 enfermeros, 2 técnicos y 2 auxiliares de enfermería. Los datos fueron analizados utilizando la técnica de análisis de contenido en la modalidad de análisis temático. Los resultados muestran que los mayores desafíos para la enfermería de ese hospital son: construir una nueva identidad, realizar el trabajo en equipo, manteniendo la identidad profesional, adquirir visibilidad en la institución, cambiar el cuidado y ampliar la administración.

DESCRIPTORES: enfermería; innovación organizacional; organización y administración

\section{SABERES E PODERES NECESSÁRIOS À RECONSTRUÇÃO DA ENFERMAGEM FRENTE A MUDANÇAS GERENCIAIS NUM HOSPITAL DE ENSINO}

Este estudo foi realizado em um hospital de ensino do Sul do país, o qual adotou modelo gerencial que provocou o desmantelamento do Serviço de Enfermagem e a desmobilização de seus trabalhadores. O objetivo geral foi promover a construção das mudanças que deveriam ser implementadas na reorganização do trabalho em enfermagem. Trata-se de estudo de caso com abordagem histórico-dialético, cujos dados foram coletados em março e abril de 2005, utilizando a técnica de grupo focal. Os sujeitos da pesquisa foram 8 enfermeiros, 2 técnicos e 2 auxiliares de enfermagem. Os dados foram analisados utilizando a técnica de análise de conteúdo na modalidade de análise temática. Os resultados mostram que os maiores desafios para a enfermagem desse hospital são: construir nova identidade, realizar o trabalho em equipe mantendo a identidade profissional, adquirir visibilidade na instituição, mudar o cuidado e ampliar a gerência.

DESCRITORES: enfermagem; inovação organizacional; organização e administração

${ }^{1}$ Paper extracted from Doctoral Dissertation; ${ }^{2}$ RN, Ph.D. in Nursing, Adjunct Professor, Universidade Federal do Paraná, Brazil, e-mail: elizaber@ufpr.br; ${ }^{3}$ RN Associate Professor, University of São Paulo School of Nursing, Brazil, e-mail: vandaeli@usp.br. 


\section{INTRODUCTION}

$I_{n}$ places where the implementation of the Brazilian Single Health System (SUS) advanced and created care networks, hospitals were fully integrated, which imposed conceptual and operational changes in terms of management.

Because the studied hospital had to adapt to the health care network model and improve its performance, it initiated, in April 2002, the implementation of a management model based on "lines of care". It refers to safe care flows provided to users to attend their needs ${ }^{(1)}$.

The organization of service by "teams" replaced the traditional rationale by "profession" in this new model. In order to adapt to this new proposal, service and unit structures underwent considerable changes, and the most symbolic one was the replacement of the Nursing Head $(\mathrm{NH})$ by the Nursing Coordination (NC).

There is the belief that some changes should be undertaken so that the care practice would be seen through a perspective different than the clinical one. However, the rationale for changing the management model, which is valid and legal to explain care in another logic, implicitly and intentionally dismantled the Nursing Service and disbanded its workers at a time of competency dispute between physicians and nurses.

Understanding that this proposal would move towards its full implementation and the need to make a decision on the repositioning of nursing in the institution, the question guiding the study was: How can nursing be promoted to become a protagonist in the change process of the study hospital's new management model, assuming and determining its own course, assuring its space, in legal and practical terms, in the development of nursing work?

The general aim of this study was to promote the re-construction of nursing in view of this new management model among nursing workers. The specific objectives were: to re-construct the historical determinants involved in the implementation of nursing management models; identify the current context of the management model, its meaning and future possibilities; identify coping strategies in terms of knowledge and power and elaborate proposals and strategies for the reconstruction of nursing at this institution.

\section{METHOD}

This research uses the case study method, which was chosen because it can contribute to understand complex social phenomena and deal with contextual conditions related to these phenomena ${ }^{(2)}$.

Since the case study is one of the most relevant types of qualitative research, whose goal is to perform a detailed analysis of a unit ${ }^{(3)}$, the results of this study are valid only for this hospital, though the knowledge acquired from its reality can allow for the formulation of hypotheses ${ }^{(3)}$.

This study is based on the Social Determination that explains the social development process in a historical and dialectic perspective. The process, in Social Determination Theory, goes against the static view of positivism and expresses the dynamic nature of facts linked to health-disease in all of its dimensions $^{(4)}$. The dialectic methodology is specific to social sciences because it is better suited to analyze historical phenomena, as the dialectic view privileges: a) contradiction and conflict predominate over consensus; b) phenomenon of change in stability; c) historical movement and d) totality and unity of opposites $^{(5)}$.

The study setting was a large public school hospital in Curitiba, PR, Brazil. The studied population corresponds to approximately 1,233 nursing professionals, who represent $34.5 \%$ of the hospital's staff. The study subjects were eight nurses, two nursing technicians and two nursing auxiliaries, totaling 12 nursing professionals who had worked in the institution for five years or more and accepted to participate in the study.

The research project was analyzed and approved by the Research Ethics Committee (No. CEP/ HC 954.184/2004-1).

Data collection was carried out during March and April 2005 through the focal group technique. This was considered the best strategy to gather different actors from professional practice in a proper space, permitting critical consideration of the situation under study $^{(6)}$.

The number of meetings was determined by three specific objectives: historical determinants involved in the change; current situation of nursing, its meanings and future possibilities; and coping strategies: knowledge and power. The meetings were recorded and transcribed. Seven meetings were required for the group members to conclude they had answered the three questions. 
Analysis of the transcribed material was composed of three phases: pre-analysis, exploration of material and data treatment ${ }^{(7)}$. Thematic analysis was chosen among the content analysis techniques, aiming to identify the "meaning" of the transcriptions.

The criteria guiding the reading were empirical categories, "constructed with an operational goal, aiming at field work"(8). These categories were established by the specific objectives. The analytical categories, "considered references for knowledge about the object in its general aspects"(8), which supported the discussion of empirical categories were: Brazilian health policies, management models adopted by hospitals, and general competencies for nursing practice.

\section{RESULTS AND DISCUSSION}

The historical determinants that influence the situation of nursing at the hospital

To recompose the category historical determinants that influence the current situation of nursing at the hospital, four determinants were identified in the nursing reality and expressed by the focal group. The first one was the estrangement of nursing and health policies.

In this category, one understands that nursing has historically, efficiently and effectively reproduced actions mainly determined by governmental policies, programs and agencies ${ }^{(9-11)}$. Therefore, the (little) power of decision nurses possess in health institutions is more focused on putting policies into operation than on formulating them ${ }^{(9)}$.

Alienated from the health policy scenario, nurses in hospital always "followed" the hospital at the top of the pyramid, with specific knowledge related to healing and management practices. With the regionalization process, hospitals are inserted in the health care network, which initially hinders the nurses' understanding on how changes in the care model affect hospital management.

Despite strong reasons in favor of changing the management model adopted by the hospital, the group believes that the command had the intention to dismantle. The command is considered, in this study, the second determinant of the current nursing situation.

The reasons presented by the group include the "appropriation" of nursing employees' complaints, presented by nursing employees, and used by the command to legitimate the abolishment of the $\mathrm{NH}$. Another reason is the rationale of the proposed model, which foresees the reduction of directors, aiming to diminish hierarchical levels. The group mentioned the political dispute and the need to "weaken" the nursing group as one of the reasons to "dismantle".

The third identified determinant is the historical organization of nursing work, related to the traditional education that privileges a culture of subordination; the rigid and hierarchical organization of work, which makes it difficult to put new models in practice; and gender and information access issues. Because of this historical organization, nursing is not prepared to make strategic decisions.

The fourth identified determinant is related to the idea that, when nurses occupy positions of trust, they no longer play the nurse's role, perceived when some nurses who assumed strategic positions in the new structure called themselves "managers" instead of "nurses".

Traditionally, nurses do not assume command positions in hospitals out of the nursing context. In the logic of professions (or hospitals), many elements can explain the nurses' unfavorable position. First, the highly hierarchical traditional model is guided by the medical healing practice that determines the role of other professions. Second, because this is a longstanding model, hospitals are unwilling to change their hierarchical structure and management. Finally, the superiority (or hegemony) of physicians in relation to nurses is frequently "hidden" by institutional mechanisms ${ }^{(12)}$.

According to the group's rationale, a more democratic, less "professional" work organization can explain and favor the rise of nurses to higher positions for many reasons, among which the administrative education of Brazilian nurses. This education favors the development of capable coordinators in areas of exchange between the dimensions of integration ${ }^{(13)}$.

Current context, its meaning and future possibilities

To recompose the category current context, its meaning and future possibilities, the focal group identified the nurses' identity crisis, caused by the loss of the $\mathrm{NH}$, experience of two concomitant models, and the hospital's high level of disorganization due to the transition from one model to the other.

Both the loss of $\mathrm{NH}$ and the difficulty in working with the two concomitant models seem to be more related to the dependency on a legitimate power than 
to an orientation. It is observed in their reports that little has changed in the nursing routine, especially in terms of care and power. It is worth highlighting the symbolic meaning of the $\mathrm{NH}$ as the single source of legitimate power in the nurses' opinion.

A "crystallization" of the model is perceived, marked by influences from Scientific Administration - division of work and work specialization, from Classical Theory - hierarchization and Bureaucracy theory - regiments, rules, and the formal nature of communication $^{(14-15)}$.

In general, nursing technicians and auxiliaries deemed there were no significant changes in terms of care. However, it is implied in the nurses' reports that care is worsening because the worker is not being cared for. In their discourse, the "tone" of fatalism stands out more than the idea per se. This is in line with the statement that the nursing work process has been affected by another order of values, contaminated by the messianic work, by suffering. In its mission and sacrifice, the representation of the professional image marks part of the constitution of nursing work $^{(16)}$

There are contradictions in their reports regarding power. Nurses said they had lost power and nursing auxiliaries that they had gained power because they got closer to their team and less dependent on a leadership.

It is necessary to use the concepts of symbolic power and symbolic capital ${ }^{(17)}$ to shed some light on the loss of the $\mathrm{NH}$. These concepts mean, respectively, power to construct reality that tends to establish an order of acknowledgment, and all and any capital, when perceived by an agent, known and acknowledged as such. Since, for nurses, the NH had a symbolic potential and its loss generated meaning, there is a feeling that they no longer belong to any group and lack acknowledgement and identity.

In terms of future possibilities, the group understands that a person or a group should conduct changes. There are no concrete perspectives, though it can be observed that careful consideration permitted as perspective, even as a distant one, of the need to accept new professional profiles required by the new management models.

Coping strategies: knowledge and power

In the reconstruction of the category coping strategies: knowledge and power, it was identified in the focal group that, because perspectives were compromised by pessimism and apathy, strategies emerged as feeble but real possibilities. Power in this category is understood as strategically and politically "necessary" so that nursing can put its care and management projects into operation. In terms of knowledge, the nurses' operational competencies at the hospital based the discussion.

It is observed in the reports that the group believes that, by mobilizing nursing, there would be a chance of reverting the current scenario and getting $\mathrm{NH}$ back, as the only way to legitimate power in the hospital structure.

Regarding the focus on $\mathrm{NH}$ as the only option, one can intentionally desire to "subject" others more than "being subject" in certain circumstances. Therefore, the capacity to act and interpret the place one is inserted in should be explored, attempting to interfere in its rules and seeking escape to new "scenarios"(18).

Based on these assumptions, one could think of another strategy so that, in case negotiation fails, the group would be able to get stronger and recover, finding in the escape to new scenarios the power needed to restructure. Specifically, it means that nursing could use "power" of knowledge, of expertise, to find new forms of working in care and management.

A second strategy of power would be to find a leadership that, according to the group, should have political competence (political connections, ability to unite people) and technical competence (professional acknowledgement at the hospital due to knowledge). This is an ambitious profile and somewhat transfers the responsibility of reconstructing to another person.

Strategies regarding knowledge are linked to a contextualized knowledge, and the need to construct their own care project is very clear, which should be in line with the health context, the institution's mission and the objectives of nursing itself.

A project can be a way, found by the group, to work conflicts, a strategy to unite, which can strengthen them in the search for a common goal. This project would reinforce (because they already acknowledge they have power in the coordination of care) or recover, through competence, more power and the reconstruction of a new identity.

Proposal for the development of nursing at the hospital

The perception of the need to change shows that the group wants and needs to restructure this 
new scenario, but the lack of motivation and preparedness in the face of the challenges made their proposals feeble. However, through discussion between all categories, it is possible to find ways, provided by the group itself, to help in the construction of other coping strategies. For this purpose, aspects had to be recalled that were considered essential for the nursing reconstruction process. The first is power and the second is knowledge.

What is seen is that power can be used to reconstruct, to recover, to restructure. Since nurses do not acknowledge the NC as a symbol of power, the first proposal is to recover individual power, or the empowering capacity each nurse possesses and which can be used in this process.

Since the "formal power" is not acknowledged, the group should consider possibilities of restructuring itself on other bases. It includes the acquisition of competences that can grant power. The acquisition of competences in general can grant power but, here, it refers to the acquisition of competences specific to the political dimension, communicative competence, citizenship development, which are inherent to the nurse's management activity ${ }^{(19)}$.

First, these dimensions comprehend the awareness of nursing workers in the perspective of their emancipation as social subjects. Second, the preservation of the unity of nursing as a category that has responsibilities towards institutional projects and users, and which has legitimacy to work on its own competence, like in the organization of nursing work for instance.

Finally, nursing should recover or conquer the right of an effective role in decisions related to the health work process in the hospital, of which it is inseparable. For that, the position should be officially acknowledged in the hospital's organizational structure.

The strategies to acquire new competences require willingness and opportunity. When considering that the acquisition of competences includes the use of knowledge in situations of action ${ }^{(20)}$, one assumes that must extract challenges and complex tasks from the context itself.

Regarding knowledge, the analysis of reports identifies that the group needs to acquire a more contextualized knowledge and, on the other hand, it shows great concern with the maintenance/update of "clinical/care" knowledge more related to care delivery, which has always conferred competence to the hospital's nursing.
We consider that the sub-processes delivering care and managing are the most present ones and that the sub-process managing can go beyond nursing limits in this new model. The knowledge needed to acquire new competences includes both management and care delivery aspects ${ }^{(19)}$. For that, these aspects should include knowledge regarding health policies and how to put them into operation in the country, city and hospital scopes. More specifically to care, new knowledge should include care practices that put the user at the center of nursing work. It is worth stressing that it is from the management perspective, considering the possibility of establishing a new direction, that these proposals are envisaged.

\section{FINAL CONSIDERATIONS}

The current context shows that the nurses' identity crisis was mainly caused by the loss of the $\mathrm{NH}$. It could be observed that nurses had a certain "longing", a "tone" of fatalism, which can lead to inertia, to an exaggerated zeal for rules, standards, protection and hidden control in one direction, whose extinction shows the loss of power and symbolic capital and represent many losses, because it resulted from a successful historical struggle.

The occupation of positions outside the nursing context establishes and expands the nursing scope of influence at the hospital. These new positions can be strategically used in its recovery. It means there is a model to be overcome: internally, in the nursing context, both in care and in management, and out of this context, in occupying positions of trust and coordination of multidisciplinary teams. These new roles need to be seen and worked as a new challenge and can benefit users and nursing workers.

It is important to stress that, when nursing assumes the whole responsibility for its recovery, it acknowledges that it lost by itself its position in the institution, which is not true. This responsibility should be shared: nursing should re-think its production process and adapt to the new care and managing profiles and the institution should acknowledge that no institutional project can be achieved without its participation. Acknowledging this fact means to institutionally respect that nursing has its own knowledge and is capable of reorganizing. It also means that the institution should take responsibility to create an institutional environment in line with the 
theoretical precepts it proclaims - to value care as its first mission and favor a system of opportunities for growth and development of its workers.

The associations, councils and schools in Brazil should be more attentive to the implementation of new managing models. The SUS guidelines regarding the care model can be respected without being used by institutions to justify "dismantles", considered increasingly more "necessary" for its implementation.

\section{REFERENCES}

1. Magalhães HMJr. Apresentação. In: Merhy EE, Magalhães HMJr, Rimoli J, Franco TB, Bueno WS. O trabalho em saúde: olhando e experenciando o SUS no cotidiano. São Paulo (SP): Hucitec; 2003.

2. Yin RK. Estudo de caso: planejamento e métodos. $3^{a}$ ed. Porto Alegre: Bookman; 2005.

3. Triviños ANS. Introdução à pesquisa em ciências sociais: a pesquisa qualitativa em educação. São Paulo: Atlas; 2002. 4. Fonseca RMG, Bertolozzi MR. A epidemiologia social e a assistência à população. In: A classificação das práticas de enfermagem em saúde coletiva e o uso da epidemiologia social. Brasil: Associação Brasileira de Enfermagem; 1997.

5. Demo P. Metodologia científica em ciências sociais. $2^{a}$ ed. São Paulo: Atlas; 1989.

6. Chiesa AM, Ciampone MHT. Princípios gerais para a abordagem de variáveis qualitativas e o emprego da metodologia de grupos focais. Brasília (DF): Associação Brasileira de Enfermagem; 1999.

7. Bardin L. Análise de conteúdo. Lisboa: Edições 70; 2000. 8. Minayo MCS. O desafio do conhecimento: pesquisa qualitativa em saúde. $8^{a}$ ed. São Paulo: Hucitec; 2004.

9. Queiroz VM, Salum MJL. Globalização econômica e a apartação em saúde: reflexão crítica para o pensar/fazer na enfermagem. In: Anais do $48^{\circ}$ Congresso Brasileiro de Enfermagem; 1996; São Paulo. São Paulo (SP): Aben; 1996. 10. Galleguillos TGB, Oliveira MAC. A institucionalização e o desenvolvimento da Enfermagem frente às políticas de saúde. Rev Bras Enferm 2001; 54(3):466-74.

11. Barbosa MA, Barreto IS, Brasil VV, Pereira MS.
In terms of acquisition of new competences, the curricular guidelines already include competences and abilities needed for professional practice exercise, in line with the SUS. The hospital nurses, who have traditional education, need to acquire these competencies, maybe with more emphasis on politics in a scenario that has already changed. To their favor, they have experience and knowledge acquired throughout many years, which qualify their work and, if they wish, a successful change.

Considerações sobre a organização política da Enfermagem J Assoc Bras Enfermagem 2003; 45(1):6.

12. Cecílio LCO, Merhy EE. A integralidade do cuidado como eixo da gestão hospitalar. In: Pinheiro R, Mattos RA, organizadores. Construção da integralidade: cotidiano, saberes e práticas em saúde. $3^{3}$ ed. Rio de Janeiro (RJ): IMS/ UERJ, CEPESC-ABRASCO; 2006.

13. Contandrioupolos A-P, Denis J-L, Touati N, Rodriguez R. Intégration des soins: dimensions et mise en œuvre. Ruptures 2001; 8(2):38-52.

14. Moura GMSS, Magalhães AMM, Chaves EHB. O serviço de enfermagem hospitalar- apresentando este gigante silencioso. Rev Bras Enferm 2001; 54(3):482-93.

15. Matos E, Pires D. A organização do trabalho da enfermagem na perspectiva dos trabalhadores de um hospital escola. Texto e Contexto Enferm 2002; 11(1):187-205.

16. Pereira A. O imaginário sobre o trabalho dos gêneros profissionais: a vertente do sofrimento e do prazer no trabalho da (o) enfermeira (o). Texto e Contexto Enferm 2002; 11(1): 105-20.

17. Bourdieu P. O poder simbólico. $8^{\mathrm{a}}$ ed. Rio de Janeiro (RJ): Bertrand Brasil; 2005.

18. Merhy EE. Saúde: a cartografia do trabalho vivo. São Paulo (SP): Hucitec; 2002.

19. Almeida MCP, Fortuna CM, Pereira MJB, Mishima SM, Villa TCS. Gerência na rede básica de serviços de: processo de trabalho saúde. In: Anais do X Encontro de Enfermagem do Nordeste; 1994; Salvador; 1994.

20. Lucchese R, Barros S. Pedagogia das competências - um referencial para a transição paradigmática no ensino de enfermagem - uma revisão de literatura. Acta Paul Enferm $2006 ; 19(1): 92-9$. 